\title{
Adjective Reduplication of Sasak Dialect Meno-Mene in Karang Bagu
}

\author{
Baiq Rismarini Nursaly
}

Universitas Hamzanwadi, Indonesia

Correspondence: Baiq Rismarini Nursaly, Universitas Hamzanwadi, Indonesia. e-mail: rismarini09@gmail.com

\begin{abstract}
This research aims to describe forms and types of adjective of Sasak dialect Meno-Mene that is spoken in Lingkungan Karang Bagu, Karang Taliwang Subdistrict, Mataram City, and West Nusa Tenggara Province. Word reduplication in a language is included in structural study of morphology. According to Verhaar (1988:52) in his book Pengantar Linguistik, morphology is a part of linguistics that studies grammatical arrangement of parts of word. Data in this research comes from utterances spoken by Sasak speakers in Lingkungan Karang Bagu. Data collection was done by using observation and interview technique. The collected data were analyzed using intralingual identity method. Result of analysis shows that the morphological process of adjective reduplication of Sasak dialect Meno-Mene in Karang Bagu was divided into 4 based on: basic word form, reduplication form, reduplication function, and reduplication meaning.
\end{abstract}

Keywords: Sasak, reduplication process, adjective, dialect Meno-Mene

\section{Introduction}

Indonesia is a country that has diversity in various aspects, such as religion, ethnicity, culture, and of course language. Indonesia has approximately 700 languages. One of these languages is Sasak used by Sasak ethnic groups on Lombok Island. According to some researchers, Sasak has many dialects, such as Tohir, et al. (1986) grouping Sasak dialect into 5 namely; Meno-Mene, Ngeno-Ngene, Ngeto-Ngete, Ngeno-Mene, and Meriak-Meriku dialects. In addition to Tohir, Arzaki also named the Sasak dialects into 5 with similar names, namely; Meno-Mene, Ngeno-Ngene, Kuto-Kute, Ngeno-Mene, and Meriak-Meriku dialects. Both researchers distinguish Sasak dialect based on the word lexicon that has the meaning "like this-like that". The Regional Office of Education and Culture Department West Nusa Tenggara, Mataram in 1990 held a General Sasak Language Spelling Seminar that tried to establish one of these dialects into a standard dialect that could be used for several official needs such as in the field of education for local content subjects. The meeting could not produce an agreement on standard Sasak, but seminar participants were willing to accept the Ngeno-Ngene dialect as a commonly used Sasak language.

Sasak languages like other languages also have rules or structures. Morphology is one part of the structure of language. Sasak generally has 3 morphological processes, namely; 
affixation, compounding, and reduplication. Nida $(1949 ; 10)$ describes morphology to be, "the study of morphemes and their arrangements in forming words", that is the study of morphemes and how to arrange these morphemes into words. This is in line with Ramlan (1979: 20) and Verhaar (1988). Ramlan mentioned that morphology is a part of linguistics that concentrates on the details of word structure along with the influence of changes in the structure of the word on groups of words, while Verhaar states the meaning of morphology with simpler sentences, namely; the linguistic field which studies the composition of word parts grammatically. Wijana (2011: 15) describes morphology as a branch of linguistics that studies the subtleties of word forms.

This paper discusses one of Sasak morphological processes, namely the reduplication system and is devoted to one type of word that is an adjective.

\section{Method}

Method in this research is the way the writer arranges, checks and groups the data to form an orderly arrangement. This study uses data derived from the Meno-Mene dialect Sasak language derived from utterances produced by Sasak speakers in the Lingkungan Karang Bagu, Karang Taliwang Village, Cakranegara District, Mataram City, West Nusa Tenggara Province. Data was taken randomly, using of observation and interview method according to Mahsun (2017). The obsevation method is a method to get data by listening to the utterances produced by Sasak language speakers in the region. Observation technique is how to get data by getting involved in the occurred utterances in the region. Both techniques were also equipped with recording and note taking techniques. The data that have been recorded and noted were then grouped based on similarities and differences. The data were then compared using intralingual identity technique, then analyzed in qualitative methods.

\section{Findings}

Reduplication or repetition is one of the morphological processes in a language about formation of a word that is from a basic form by repeating the basic form. Reduplication produces a word called the repeat word. The repeat word can be a single word that only consists of one basic morpheme or it can be a complex word (an affixed word or compound word) that is a word consisting of two or more morphemes.

Based on the basic form, the repeat word in Sasak can be divided into 6, namely: repetitive nouns, repetitive pronoun, repetitive numeralia, repetitive verbs, repetitive adjectives, and repetitive particles. In this paper, the problems raised are limited to repetitive adjectives or repetitive adjectives in the Meno-Mene dialect.

Repetitive adjectives of Sasak are divided into 4:

1. Based on basic word form;

1.1 Repeat basic adjectives,

1.2 Repeat affixed adjectives:

1.2.1 Full repeat affixed adjectives,

1.2.2 Partial repeat affixed adjectives 
1.3 Repeat compound adjectives:

1.3.1 Full repeat compound adjectives,

1.3.2 Part repeat compound adjectives.

2. Based on reduplication form:

2.1 Dwilingga form adjectives,

2.2 Dwipurwa form adjectives.

3. Based on reduplication function:

3.1 Forming verbs (verbalization),

3.2 Forming nouns (nominalization).

4. Based on reduplication meaning:

4.1 Forming plural meaning

4.2 Forming emphasization meaning.

\section{Discussion}

Adjectives (Adj) and verbs (V) of Sasak language have same nature in the formation of phrases and sentences. These two types of words cannot fill the position of object. If these two types of words are negated or changed into a negative form must be preceded by the words "ndeqna" and "iyaqna" that means "no". Therefor the both types of words are included in one part of speech, namely adjectives (Adj), but both word types can still be distinguished because both Adjand V have their own characteristics. Example; V in Sasak can be preceded by the words "ndeq, ndaq, iyaq" which means "do not (jangan)" or can also be preceded by the words "ndeq-ndeq, ndaq-ndaq, iyaq-iyaq" which means 'not-not'. The aforementioned words cannot precede Adj, because Adjcan only be preceded by the words "ndeqna" and "iyaqna". Moreover, Adjcan be preceded by the word "langsot" means "very". Adjis also repeated and affixed by the prefix and suffix $\{s e-\ldots-n a\}$ 'se-...nya' or $\{a h-\ldots-a n\}$ 'se-...nya'.

Based on some of the characteristics listed above, Sasak can be determined, for example the word "kodeq" "small' is an adjective because it can be preceded by the word "ndeqna" 'very' so that it becomes "ndeqna kodeq" 'not small' or can be preceded by the word "langsot" means "very" so that it becomes "langsot kodeq" "very small", or can be repeated and affixed with a prefix and suffix $\{$ se-...-na\} so that it becomes "sekodeq-kodeqna" 'as small as possible'.

Adjin Sasak is generally basic morpheme. If Adjundergoes affixation process in general, it will change to $\mathrm{V}$ or $\mathrm{N}$. For example, the basic Adjmorpheme "abang" "red", if it is given suffix $\{$-ang\}, the word type changes to $\mathrm{V}$ "abangang" 'redden'. Another example is the basic Adjmorpheme "beleq" "big" after being prefixed and suffixed $\{\mathrm{N} . .$. -ang $\}$ 'di- ... -kan', then the word type changes to V "mbeleqang" "raised", if the word "beleq" is prefixed \{pe-\} then the word type changes to $\mathrm{N}$ "pembeleq" "enlarger". There is also basic Adjmorpheme that is affixed does not change its word type such as Adj"putiq" "white" given suffix $\{$-an $\}$ to "putiqan" "whiter". In addition, there is basic Adjmorpheme that does not change its word type after experiencing compounding process, for example the word "peteng" "dark" combined with a unique morpheme "dedet" will be "peteng dedet" "pitch black". The word 
"peteng" or "peteng dedet" is still including in Adj. Adjectives with this form are called compound Adj.

1. Adjective that is based on basic word form

1.1 Repeat basic adjectives

Its basic form is a basic Adjmorpheme. Each basic Adjmorpheme in Sasak can undergo a reduplication process for both full reduplication (dwilingga) and partial reduplication.

Example:

bideng 'hitam' 'black' > bideng-bideng 'hitam-hitam'

lenge 'jelek' 'ugly' > lenge-lenge 'jelek-jelek'

enges 'cantik' 'beautiful' > enges-enges 'cantik-cantik'

adeng 'pelan' 'slow' > adeng-adeng 'pelan-pelan'

luweq 'banyak' 'a lot'> luweq-luweq 'banyak-banyak'

galuh 'luas' 'large' > galuh-galuh 'luas-luas'

Examples of sentence:

1. Ndaq bebale rapet-rapet segara.

Jangan berumah dekat-dekat pantai.

Do not have house so near to beach.

2. Ndaq gelis-gelis merariq, anta masi bajang gati.

Jangan cepat-cepat menikah, kamu masih muda sekali.

Do not get married so early, you are so young.

3. Awaqku marak irapna sik polaq-polaq.

Badanku terasa seperti patah-patah.

My body feels so broken.

4. Makaq ceredeh-ceredeh laloq mpaq tie?

Kenapa kecil-kecil sekali ikan itu?

Why the fishes are so small?

All of the examples above include in the full repeat basic adj. The basic Adjmorpheme consisting of two syllables can only experience full repeat process, while the basic Adjmorpheme consisting of three syllables, can be fully repeated and also be partial repeated. Like the last sentence example, the word "ceredeh" gets reduplication process to be "ceredehceredeh" or "ceredeh-redeh". The three-syllable basic Adjmorpheme is not found in many examples in the Meno-Mene dialect. Here are some examples of sentences using Adjwhich consists of three syllables that can experience partial reduplications:

1. Dengan Sasak jerema-rema lek temue.

Orang Sasak ramah-ramah kepada tamu.

Sasak people are so friendly to the guests.

2. Kembeq bi deqang dirikm kerebo-rebo.

Kenapa kamu (pr) membiarkan dirimu basah-basah.

Why do you let yourself be so wet? 


\subsection{Repeat affixed adjectives}

Its basic form is the affixed Adjwhich in this case is limited to the suffixed $\operatorname{Adj}\{-\operatorname{an}\}$ 'over', that can undergo the reduplication process of both full and partial reduplication. Thus, based on the way repeating basic form, repeat affixed Adjcan be divided into two: full repeat affixed Adj and partial repeat affixed Adj.

1.2.1 Full repeat affixed adjectives

Its basic form is affixed Adj, that is suffixed Adj $\{-$ an $\}$. Adj with suffix $\{-a n\}$ can 'more' undergo reduplication process without changing its meaning.

Sentence example:

1. Tangkong seragamn puteqan-puteqan leman seragam bi. Baju seragamnya lebih putih-lebih putih dari seragammu (pr). Her uniform is whiter than your uniform.

2. Maiqan-maiqan bae nasiq poyong timbang nasiq meang dik. Lebih enak-lebih enak nasi bungkus dari pada nasi yang dimasak sendiri. It is more delicious bought rice one than self-cooked rice one.

3. Ndak girang betanding jelapan-jelapan mangan, laun kesarukm. Jangan sering bertanding lebih cepat-lebih cepat makan, nanti kamu tersedak. Do not compete to be faster eating, or you will choke on food.

\subsubsection{Partial repeat affixed adjectives}

Its basic form is suffixed Adj $\{-a n\}$ 'more'. Each Adj that has suffix $\{-a n\}$ and has meaning 'more' can undergo partial reduplication process, nevertheless this form is more directed at the meaning of 'comparing'. This form usually is used by children to talk and invite friends to compete about something (nature). Many partial repeat affixed Adj examples are found in the form of 'invitations' that are usually preceded by the word ' $k e$ ' which means 'come on' or 'let's'.

Sentence example:

1. Ke betanding lais-laisan dedagangan! Mari kita berlomba siapa yang lebih laris dagangannya! Let's compete who will sell more!

2. Ke te nyereng-nyerengan aik inem! Ayo siapa yang lebih jernih air minumnya!

Let's see whose drinking water is clearer!

\subsection{Repeat compound adjectives}

Its basic form of repeat compound Adj is certainly compound word. Each compound Adj can undergo reduplication process, for both fuul reduplications or partial reduplication. For example, compound the "bireng jenget" "solid black" can be repeated fully into "bireng jenget-bireng jenget" or "pitch black-pitch black" or can be repeated partly to be "birengbireng jenget" "pitch black-pitch black".

\subsubsection{Full repeat compound adjectives}

Its basic form is compound Adj. Compound Adj can be fully repeated to be full repeat Adj. 
Sentence example:

Dagang oat lek Peken Sindu no kawih speker beleq ke biyur lantur-biyur lantur.

Pedagang obat di Pasar Sindu menggunakan pengeras suara besar sehingga suaranya hiruk pikuk-hiruk pikuk.

The medicine seller in Sindu Market uses big loud speaker so it sounds so noisy.

Kanak saq demen bekedeq tengari galeng awakne bireng keleseng-bireng keleseng.

Anak yang suka bermain di bawah terik matahari badannya menjadi hitam mengkilathitam mengkilat.

The children who like to play under the sun, their body become jet black.

\subsubsection{Part repeat compound adjectives}

Its basic form is compound Adj. Sasak compound Adj generally, based on research conducted by the Center for Language Development and Maintenance of the Ministry of Education and Culture in 1984 concerning Sasak Reduplication System that consist of two elements. These two elements are basic morphemes, for example "Putiq kuning" "white yellow". However, there is also compound Adj that one of which is a unique morpheme. The unique morpheme of such compound words is always the second element, for example, 'bireng leteng' 'solid black' consists of the basic morpheme 'bireng' 'black' and the unique morpheme 'leteng' 'thick'. If the compound Adj undergoes partial repetition, it is only the first element that is repeated.

Sentence example:

1. Sai pelentong kanak tie, ka beyaq-beyaq bengkek bakatn.

Siapa yang melempar anak ini, lukanya merah-merah sekali.

Who pelt the kid, his wound is so red.

2. Terong aceh lek bangket Papuq Odah keceq-keceq keok.

Tomat di sawah Kakek Odah kecil-kecil sekali.

Tomatoes in Grandpa Odah's ricefield are so small.

3. Arak apa to lapangan makak rame-rame rumiya lalok.

Ada acara apa ya di lapangan, kenapa ramai-ramai sekali.

What event is there in the field? It is so noisy.

2. Adjectives (adj) based on reduplication form

2.1 Dwilingga form adjectives

The dwilingga form adjective in Sasak is very productive. The dwilingga Adjs are widely used to pluralize nouns in front or behind the adjective.

Sentence example:

1. Amun sabol-sabol isik bukum, lemak gelis roek tas tie.

Kalau mengisi bukumu penuh-penuh nanti ta situ cepat rusak.

Do not fill your bag so full, it can make your bag broken.

2. Gang lek kampung Bali gamber-gamber.

Gang di kampung Bali lebar-lebar.

The alleys in Kampoong Bali are so wide.

3. Mantaq berangen lek arikke mun sekedar demen-demen doang.

Jangan naksir adikku kalau sekedar suka-suka saja.

Do not play with my sister's heart if you only crush on her. 
4. Ke solah-solah dedare sak ngelamang lek mall.

Betapa cantik-cantiknya remaja yang berjalan-jalan di mall.

The girls who are window shopping at the mall are so pretty.

\subsection{Dwipurwa form adjectives}

There are not too many dwipurwa found in Sasak basic morphemes. The use of this form is low and unproductive. If it undergoes dwipurwa Adj, it will change to noun $(\mathrm{N})$ and some will change to verb (V). Examples of Adj basic morpheme in the form of dwipurwa that change to nouns $(\mathrm{N})$;

Beyaq 'merah' 'red' > bebeyaq 'anak-anak' 'children' (N)

Pait 'pahit' 'bitter' > pepait 'nama jenis ikan yang kecil-kecil' 'name of small fishes' $(\mathrm{N})$

Pedis 'kecut' 'sour' > pepedis 'buah-buahan yang rasanya kecut' 'sour fruits' $(\mathrm{N})$

Bais 'bau' 'bad smell' > bebais 'nama sejenis bunga' 'name of flower' $(\mathrm{N})$

Lemu 'enak/gurih' 'delicious' > lelemu 'lemak' 'fat' (N)

Sentence example:

1. Bebeyaq ndek kanggo sugul bale waya magrib.

Anak-anak kecil tidak boleh keluar rumah saat magrib.

The children are not allowed to get out when it is dusk.

2. Pepait maiq gati piak pes campur nyiur odaq.

Ikan kecil-kecil sangat enak dibuat pepes yang dicampur dengan kelapa muda.

The small fishes are so delicious to make pepes mixed with coconut.

3. Pepedis girang tepete sik dengan ngidam.

Buah-buahan yang kecut sering dicari oleh orang yang sedang ngidam.

The sour fruit are often searched by craving people.

Examples of Adj basic morpheme that change into verb after changing the form into dwipurwa are;

Peteng 'gelap' 'dark' > bepeteng 'bergelap-gelap' 'be darking'

Bao 'teduh' 'shade' > bebao 'berteduh' 'sheltering'

Panas 'panas' 'hot' > bepanas 'berpanas-panas' 'being hot'

Sentence example:

1. Kembeq pade demen lalok bepeteng?

Kenapa kalian senang sekali bergelap-gelap?

Why do you like staying at the dark?

2. Amun bi kujanan lek langan jelapan bebao agen ndakm basaq.

Kalau kaтu kehujanan di jalan, segera berteduh supaya kamu tidak basah.

If you get rained on the road, search for sheltering soon to keep you dry.

3. Lelah ke baraq kanak-kanak tie ndakn pade bepanas.

Aku lelah memberitahukan kepada anak-anak itu untuk tidak berpanas-panas.

I am so bored to tell the children not to playing under the hot.

3. Based on reduplication function

Based on the reduplication function, basic Adj morpheme functions as verbalization and nominalization. 


\subsection{Verbalization}

In Sasak the basic adjective morpheme can change its type to verb after the first syllable is repeated so that it is called verb construction. However, not all adjective basic morphemes can undergo such changes. Examples of this changes are found very limited number. From the collected data, there are only three examples can be found. Dwipurwa Adj changes its type to verb (V). The example is exactly the example as stated above, namely; bepeteng, bebao, and hot.

\subsection{Nominalization}

Adjectives in the form of dwipurwa and dwilingga basic morphemes after reduplication can form nouns (nominalization), although there are not too many examples are found. This happens because dwipurwa and dwilingga Adj are unproductive.

Sentence Example:

Puteq 'putih' 'white'> peputeq 'kain putih' 'white cloth'

Towaq 'tua' 'old' > tetowaq 'ketua/orang yang dituakan' 'the chief/the elderly one'

Basaq 'basah' 'wet' > bebasaq 'kain basahan' 'work clothes/breast clothes'

Sengka 'sukar' 'difficult' > sesengka 'penghambat' 'obstacle'

Seret 'tidak lancar' 'not swift' > seseret 'kunci' 'key'

Sentence example:

1. Inaq mbe taok da koloq seseret bale?

Ibu di mana diletakkan kunci rumah?

Mum, where is the key?

2. Lemak te pade lalo jok tetowaq adat nunas tulung.

Besok kita bersama-sama ke ketua adat untuk meminta pertolongan.

Tomorrow we will meet the chief to ask for help.

3. Loeq dedare mandiq to segara kawih bebasaq.

Banyak gadis-gadis mandi di laut menggunakan kain basahan.

Many girls have bathing at the sea wearing breast clothes.

4. Dakaq beleq agenm lek teruna no, bilin bae loeq laloq sesengka.

Walaupun kamu sangat menyukai laki-laki itu, tinggalkan saja terlalu banyak penghambat.

Though you really like the guy, just let him go, since there are too many obstacles for you both.

4. Adjective reduplication meaning

4.1 Plural Meaning

Reduplication of adjectives has plural meaning. The plural meaning in this case shows the number of objects explained by the Adj. We know that the objects are plural even though the name of the object mentioned does not experience reduplication. It is the Adj that explains the object undergoes reduplication.

Sentence example:

1. Selapuq dengan mame sak ngerokok tao mileq mako sak solah-solah.

Semua laki-laki yang merokok pandai memilih tembakau yang bagus-bagus.

The smoking men know how to choose good tobaccoes.

2. Anaq Mamiq Amin wah beleq-beleq. 
Anak Pak Amin sudah besar-besar.

Pak Amin's children are grown ups.

3. Bau wah paoq tie wah towaq-towaq.

Petik saja mangga yang sudah matang-matang.

Only pick the riped mangoes please.

The repetitive Adj solah-solah shows plural meaning that explains good tobaccos are more than one type (plural). This case also applies to the example number 2, in which repeated Adj beleq shows that Pak Amin's children are more than one. The Adj towaq shows that there are many ripe mangoes.

\subsection{Emphasization Meaning}

For certain sentence, reduplication Adj has emphasization meaning. For example, reduplication Adj in below sentence example:

1. Beleq-beleq ngkatm ngeraos bueq biur desa.

Keras sekali bicaramu sampai terdengar di seluruh kampung.

Your voice is so loud till be heard all around kampong.

2. Tangkong toaqne dakaqn lenge-lenge laguq kemaiq irapn tekawih.

Baju tua ini walaupun jelek sekali tetapi sangat nyaman dipakai.

This shirt is so poor, but it so comfortable to wear.

3. Dakaqn bireng-bireng laguq loeq dedare meleqn,

Walaupun dia hitam sekali tetapi banyak gadis menyukainya.

Though he is so dark, many girls like him.

\section{Conclusions}

The reduplication process is one of the morphological processes in Sasak that plays an important role. This is evidenced by every type of word in Sasak that can experience reduplication process.

This paper describes the adjective reduplication (Adj). Adjectives in Sasak are divided into three, namely; basic adjectives, affixed adjectives, and compound adjectives. These three forms of adjectives can experience reduplication process for both full and partial. Adjective reduplication function is to form nouns and verbs. In addition, based on the meaning caused by adjectives reduplication is to indicate plural meaning of the object explained by the adjective and to indicate meaning of emphasis or intensify.

\section{Acknowledgement}

I would like to thank to my Promoter Prof. Dr. I Dewa Putu Wijana, S.U., M.A. and CoPromoter Prof. Dr. Mahsun, M.S. for all their guidance and advice during the writing of this dissertation.

\section{References}

Aridawati, Ida Ayu, dkk. 1995. Struktur Bahasa Sasak Umum. Jakarta: Pusat Pembinaan dan Pengembangan Bahasa Departemen Pendidikan dan Kebudayaan 
Mahsun. 2017. Metode Penelitian Bahasa: Tahapan, Strategi, Metode, dan Tekniknya. Depok: PT RajaGrafindo Persada

Nida, Eugene. 1949. Morphology the descriptive of words. New York: Second Edition Ann Arbor The University of Michigan Press

Ramlan, M. 1981. Ilmu Bahasa Indonesia: Sintaksis. Yogyakarta: UP Karyono 1965. Morfologi: Suatu Tinjauan Deskriptif. Yogyakarta: Karya Muda

Sudaryanto. 1982. Metode Linguistik: Kedudukan, Aneka Jenisnya, dan Faktor Penentu wujudnya. Yogyakarta: Fakultas Sastra dan Kebudayaan Universitas Gadjah Mada

Tohir, Nazir, dkk. 1985. Tata Bahasa Sasak. Jakarta: Proyek Pengembangan Bahasa dan Sastra Indonesia dan Daerah 1984. Sistem Perulangan Bahasa Sasak. Jakarta: Pusat Pembinaan dan Pengembangan Bahasa Departemen Pendidikan dan

University Press.

Verhaar, J.W.M. 1988. Pengantar Linguistik. Yogyakarta: Gadjah Mada University Press

Wijana, I. D.P. 2011. Berkenalan dengan linguistic. Yogyakarta: A. Com Press 